\title{
Farmers Adaptation Strategies to the Effect of Climate Variation on Rice Production: Insight from Benue State, Nigeria
}

\author{
Idoma Kim $^{1, *}$, Ikpe Elisha ${ }^{1}$, Ejeh Lawrence ${ }^{2}$, Mamman Moses ${ }^{1}$ \\ ${ }^{1}$ Department of Geography, Ahmadu Bello University, Nigeria \\ ${ }^{2}$ Department of Geography, Federal College of Education, Nigeria
}

Copyright $@ 2017$ by authors, all rights reserved. Authors agree that this article remains permanently open access under the terms of the Creative Commons Attribution License 4.0 International License

\begin{abstract}
The study investigated farmers' adaptation strategies to the effect of climate variation on rice production in Agatu Local Government Area of Benue State. Specifically, the study assessed the socio-economic characteristics of farmers, farmers' climate related constraints, the adaptation strategies employed by farmers and barriers to adaption practices. Multi-stage sampling technique was used to select two hundred and forty respondents for the study. Data collected through questionnaire were analyzed using frequency counts, percentages, mean distribution and Pearson Product Moment Correlation. Results obtained showed that farmers in the study area were mostly males with a mean age of 42.8 years. Major climate related constraint cited were high rate of weed growth $(\bar{\chi}=2.8)$, stunted growth $(\bar{\chi}=3.2)$, incidence of flooding $(\bar{\chi}=2.6)$ and low rainfall $(\bar{\chi}=3.4)$. Pearson product moment correlation indicated that there were significant and positive relationships between perceptions of climate change indicators (increasing flood, increasing hot temperature, unpredictable rain and shorter duration of rain) and adaptation strategies. Therefore, efforts should be geared towards reinforcing farmers' adaptability to climate change through improved rice species that are tolerant to change in climate elements and weather extremes like flood and drought, enhancement of farmers' income through provision of credit facilities and encouragement of irrigation farming as supplements to rain fed agriculture in the study area.
\end{abstract}

Keywords Adaptation, Benue State, Climate Variation, Rice Production

\section{Introduction}

Sufficient food production is among the principal challenges facing many developing countries. These challenges arose due to population growth, climate change and myriads of other environmental constraints (1). Hence, ensuring food and nutrition security in rural communities that are highly vulnerable to climatic variability have become increasingly complex. Importantly, the recent argument on climate change has led to reawaken attention on climate change effects on agriculture. Increasing temperatures (a sudden hot spell or cold snap) and variations in rainfall patterns (a lengthy period of insufficient or excessive rainfall) impact negatively on agricultural yields of both rain-fed and irrigated crops (2). These effects are manifested through crop yields, water availability, pests and disease, animal health and other biophysical factors. (3). However, for centuries rural farmers have evolved various survival strategies to combat the adverse effects of climate variability on crop production. Some of these schemes are multiple cropping systems, cropping drought resistant or drought tolerant crops and diversification of livelihood activities (4)

Nigeria is one of the countries in the world that has the potentials to produce rice in larger quantity. This is a fact because Nigeria has an estimated 4.6 million hectares of land that is suitable for rice production (5). Similarly, Agatu LGA has a large fadama land suitable for the production of rice and other varieties of agricultural produce. (6). However, in Nigeria, rice production is already under pressure on the demand side due to population growth, whereas the supply side is further exposed to natural pressures through climate change. There is therefore a prevailing demand-supply gap for rice in Nigeria.

Several studies $(7 ; 8 ; 9 ; 10 ; 11)$ have examined the effects of weather variations on crop production including rice and various adaptation practices of farmers in Sub-Saharan Africa (SSA) and beyond. However, the outcome in a given location depends on the magnitude of these changes, the response of the particular crops and location-specific management. Hence, to understand location specific impacts 
of climate change on agronomic crop production and to recommend appropriate remedial measures, it is pertinent to investigate climate change impact and farm level adaptation using farm level survey data. This is the rationale for this present study: Farmers' Adaptation Strategies to the Effect of Climate Variation on Rice Production in Agatu Local Government Area of Benue State. Hence, the following objectives guided the process of research:

I. identify the socio-economic characteristics of rice farmers in the study area

II. evaluate farmers' awareness and knowledge of climate variability in the study area

III. examine farmers' climate related constraints to rice farming

IV. assess the adaptation strategies employed by farmers to ameliorate climate related constraints to rice production

V. investigate the impediments to adaptation practices in the study area.

The following hypothesis stated in the null form (Ho) was tested:

Ho: There is no significant relationship between rice farmers' perception of climate variability and impact on rice yield.

\section{Theoretical Background to Rice Production in Nigeria}

Nigeria, with many countries across the world, has ecologies that are suitable for the production of different rice varieties. Therefore, proper exploitation of these ecologies can boost rice production to meet domestic demands, as well as to produce surplus for export (There are no sources in the current document.). There is no gainsaying the fact that the country has a potential land area for rice production of between 4.6 million and 4.9 million ha. However, only 1.7 million ha, or 35 percent of Nigeria's total land mass, is cropped to rice. The cultivable land to rice is spread over five major ecologies - upland, inland or shallow swamp, irrigated rice, deep water or floating rice, and tidal mangrove or swamp. The latter is not fully developed because there is a lack of appropriate technology (13). Rice is an important food item as it forms the main part of the diet of over one third of the world's population. It is among the most valued cereal crops of West African and has become increasingly used as a constituent of animal feed. Rice is rich in protein and carbohydrate, the outside layer of the rice grain which is removed during polishing is known as rice bran. Bran is rich in protein and vitamins and is widely used in the formulation of poultry feed (14). Besides, it is low in fat and protein, compared with other cereal grains. Rice also provides minerals, vitamins and fiber, although all constituents except carbohydrates are reduced by milling. (15)

According to (16) and (17), Nigeria is one of the largest rice producers in West Africa, producing an average of 3.2million tons of milled rice for the past 7 years. In Nigeria, rice is also one of the key cereal grains taking the place of some of the grains and tuber crops. Rice was once reserved for ceremonial occasions in the Nigerian diet (18).However, combinations of several elements appear to have triggered the structural increase in rice consumption. As stated by (18), rising demand was partly the result of increasing population growth as well as increased income levels, following the discovery of crude oil. The most important factor contributing to the shift in consumer preferences away from traditional staples and towards rice is rapid urbanization and associated changes in family occupational structures (19).

Instructively, (20) and (21) remarked that rice production in the country increased significantly in the periods 1980 to 1998 due to increase in land area put into rice production. The studies revealed that aggregate rice production in Nigeria increased from about 600,000 metric tons in 1980 to about 1,422,000 metric tons in 1989. In addition, (22) and (23) further showed that, out of the 4.6 million hectares of potential rice land across the country, the area put into rice production rose from 1.0 million hectares (22.3\%) in 1988 to 1.8milion hectares (39.0\%) in 1996 and 1998.

Before the introduction of World Bank Rice Project and River Basin Development Authorities in Nigeria, domestic rice production depended predominantly on natural rainfall which was very unpredictable in nature. Consequently, farmers employed traditional practices and inputs ensuing low yields. However, rice production then was commensurate with increasing demand for rice (24). Lately, Nigeria has not been able to attain self-sufficiency in rice production despite increasing hectares put into production. This situation as stated by (25) prompted the Federal Government to import rice to supplement local production and to bridge the gap between domestic demand and supply. Hence, (26) observed that Nigeria currently spends about a billion Naira daily importing rice. Similarly, the United States Department of Agriculture reveals that, Nigeria's rice imports in 2012 to 2013 alone were estimated to reach about 3 million tones. This is mainly for the reason that, the anticipated increase in rice production in 2012 to 2013 fell short of consumption requirements (27). Several efforts were made by the government to improve rice production in Nigeria. These include; ban on rice importation, the presidential initiative on rice (2004-2007) and the Agricultural Transformation Agenda (ATA) (2011). Efforts were also made to sustain production by developing effective marketing strategies through commercialization (28).

\section{The Impact of Climate Change on Rice Production}

Crop farming is extremely vulnerable to climate change. It has been predicted that climate change will impact negatively on agricultural yield in the 21st century through 
higher temperatures, more variable rainfall and extreme climate events such as floods, cyclones, droughts and rising sea levels (29; 30). Consequently, (29) noted the vulnerability of agriculture to climate change has made the scientific and policy communities to be doubtful of the capacity of farmers to adapt to climate change. In the same vein, (29) observed that The United Nations Framework Convention on Climate Change also identifies the threat to food production as a major worry. It is instructive to note that water scarcity is basically ascribed to factors such as climate change and population growth. Though, climatic changes manifested through weather extremes in the form of floods and droughts are likely to further increase the competition for water. However, it is population growth and the resultant increase in demand for food production that puts the greatest pressure on water availability. According to (30), irrigated agriculture produces approximately $40 \%$ of the world's food crops. The water use required for this crop production accounts for $70 \%$ of all water withdrawals (31). Hence, to respond to the ever growing competition for water, researchers and policy makers resolve that the role of irrigated agriculture is germane.

According to FAO by 2030, irrigated land for agriculture will expand 20 percent in developing countries with an associated $14 \%$ increase in water withdrawals for crop production. The greatest expansion of irrigated land will occur in South Asia, East Asia and countries located in East and North Africa (32). Importantly, (33) remarked that the degree of the impact of climate change on crop production will depend upon the magnitude of the climate change and other factors. Basically, increasing temperature will directly impact crops by affecting their physiology; it will also indirectly affect crops through changes in the water regime and the increased intensity of pests and diseases. Crops are also bound to be affected by more intense rainfall and other extreme weather events occurring at different stages of production.

Yet, the challenge for rice production is double: coping with population growth while also facing climate change. The changes associated with global warming in temperature, carbon dioxide and rainfall are expected to impact rice production. Studies $(34 ; 35 ; 36)$ have revealed that increase in temperature due to climate change adversely affect rice crop physiology, ultimately decreasing crop yields and grain quality. Furthermore, uncertainty related mostly to anticipate precipitation spatial and temporal patterns caused by climate change, makes it difficult to project the full effect of intensified frequency of floods and severe droughts (37). Hence, it is important to note, that in regions with more radiation, rice production results in higher grain yields. Generally, researchers have acknowledged that climate change has a positive effect on rice grain yield. The effects of increase in carbon dioxide have been found to be invalid by the effects of increase in temperature (38). However, multiple sources of bias make estimates of climate change impact on rice production uncertain. The magnitude of the bias is estimated to range between 1 to 32 percent (39). Uncertainty in projections results from climate models, spatial resolution, crop models and to add an additional level of complexity, rice cultivation strongly depends on farmers' management skills: rice variety, cropping pattern, infrastructure improvements, etc. (40)

\section{Materials and Methods}

\subsection{Description of the Study Area}

Agatu LGA was created on the $1^{\text {st }}$ of October; 1996 . It is made up of 10 wards, stretches from latitude of $7^{0} 45^{1}$ and $8^{0}$ $\mathrm{N}$ and longitude of $7^{0} 50^{1}$ and $8^{0} \mathrm{E}$ at the Northwest of the State (41). Agatu has a total area of about $1001 \mathrm{~km}^{2}$, with a population of 115,597 people (2006 census). Agatu is bordered by Nassarawa state in the North, Apa Local Government Area in the South, Gwer West in the East and Omala Local Government (Kogi State) in the West (Fig. 1). It has two distinct seasons, the rainy season $(900-1200 \mathrm{~mm}$ of rainfall) which lasts from April to October and the dry season which begins from November to March. Temperature of the study area is between 23 to $35^{\circ} \mathrm{C}$ (42) Agatu Local Government is principally an agrarian community and has the largest fadama land in Benue state. Its vast fertile land is tilled by the farming population giving rise to a variety of agricultural produce. However, its location at the bank of river Benue makes it susceptible to flooding which causes great havoc to farming activities almost annually. 


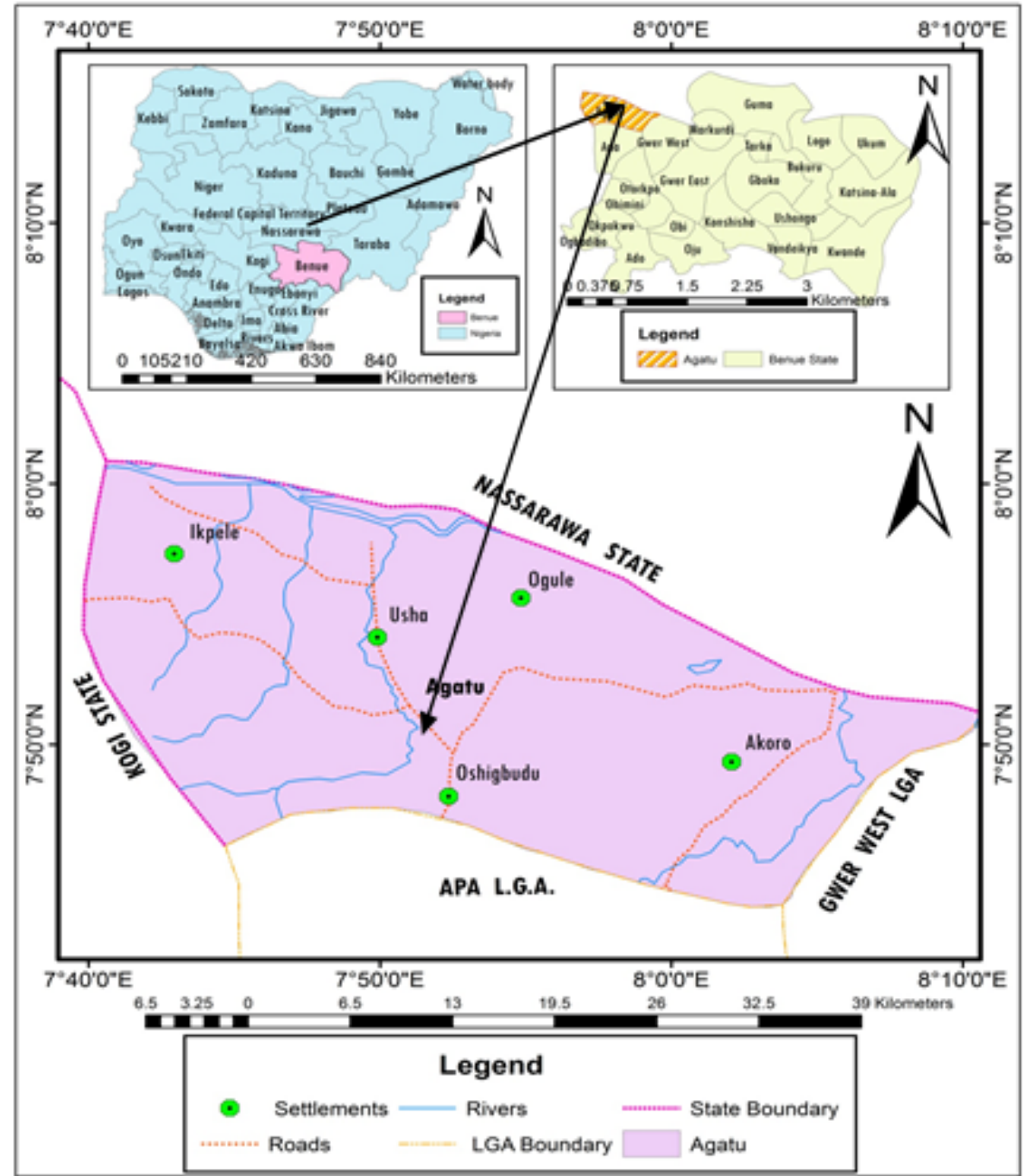

Source: GIS Unit, Ahmadu Bello University, Zaria. Kaduna State.

Figure 1. Study Area

Table 1. Composition of Interviewed Smallholder Farmers by Gender

\begin{tabular}{|c|c|c|c|}
\hline Village name & Male & Female & 24 \\
\hline Oweto & 17 & 7 & 24 \\
\hline Utugolugwu & 19 & 5 & 24 \\
\hline Ikpele & 15 & 9 & 24 \\
\hline Obishu & 20 & 4 & 24 \\
\hline Aila & 14 & 10 & 24 \\
\hline Inoli & 21 & 3 & 24 \\
\hline Olegochepo & 13 & 11 & 24 \\
\hline Abugbe & 15 & 9 & 24 \\
\hline Obagaji & 16 & 8 & 24 \\
\hline Ocholonya & 16 & 8 & 240 \\
\hline Total & 165 & 75 & \\
\hline
\end{tabular}

Source: Field Survey, 2015 
Table 2. Distribution of respondents by Age, Sex and Marital Status

\begin{tabular}{|c|c|c|c|c|c|c|c|}
\hline \multirow[b]{2}{*}{ Characteristics } & \multirow[b]{2}{*}{ Number } & \multirow[b]{2}{*}{ Percentage } & \multirow[b]{2}{*}{ Mean } & \multicolumn{2}{|c|}{ Male } & \multicolumn{2}{|c|}{ Female } \\
\hline & & & & No. & $\%$ & No. & $\%$ \\
\hline \multicolumn{8}{|l|}{ Age } \\
\hline Less than 20 & 19 & 7.9 & & 14 & 5.8 & 5 & 2.1 \\
\hline $21-25$ & 27 & 11.2 & & 25 & 10.4 & 2 & 0.8 \\
\hline $26-30$ & 24 & 10 & & 18 & 7.5 & 6 & 2.5 \\
\hline $31-35$ & 33 & 13.7 & 42.8 & 25 & 10.4 & 8 & 3.3 \\
\hline $36-40$ & 48 & 20 & & 38 & 15.8 & 10 & 4.2 \\
\hline $41-45$ & 44 & 18.3 & & 28 & 11.6 & 16 & 6.7 \\
\hline $46-50$ & 23 & 9.6 & & 14 & 5.8 & 9 & 3.8 \\
\hline Above 50 & 22 & 9.2 & & 19 & 7.9 & 3 & 1.3 \\
\hline Total & 240 & 100 & & & & & \\
\hline \multicolumn{8}{|l|}{ Sex } \\
\hline Male & 165 & 68.8 & & & & & \\
\hline Female & 75 & 31.2 & & & & & \\
\hline Total & 240 & 100 & & & & & \\
\hline \multicolumn{8}{|l|}{ Marital Status } \\
\hline Single & 62 & 25.8 & & 36 & 15 & 26 & 10.8 \\
\hline Married & 86 & 35.8 & & 58 & 24.2 & 28 & 11.6 \\
\hline Divorced & 56 & 23.3 & & 23 & 9.6 & 33 & 13.7 \\
\hline Widowed & 36 & 15.1 & & 12 & 5.0 & 24 & 10.1 \\
\hline Total & 240 & 100 & & & & & \\
\hline
\end{tabular}

Source: Field Survey, 2015.

Table 3. Distribution of respondents by Household size, Education and Income Status

\begin{tabular}{|c|c|c|c|c|c|c|c|}
\hline & & & & Male & & Female & \\
\hline Characteristics & Number & Percentage & Mean & No. & $\%$ & No. & $\%$ \\
\hline \multicolumn{8}{|l|}{ Household size } \\
\hline $1-5$ & 66 & 27.5 & & 42 & 17.5 & 24 & 10 \\
\hline $6-10$ & 94 & 39.2 & & 64 & 26.7 & 30 & 12.5 \\
\hline $11-15$ & 52 & 21.7 & 11 & 37 & 15.4 & 15 & 6.3 \\
\hline Above 16 & 28 & 11.6 & & 11 & 4.5 & 17 & 7.1 \\
\hline Total & 240 & 100 & & & & & \\
\hline \multicolumn{8}{|l|}{ Education } \\
\hline No Formal education & 52 & 21.7 & & 29 & 12.1 & 24 & 9.6 \\
\hline Primary & 69 & 28.8 & & 55 & 23.0 & 14 & 5.8 \\
\hline Secondary & 66 & 27.5 & & 45 & 18.8 & 21 & 8.7 \\
\hline Tertiary & 53 & 22.0 & & 37 & 15.4 & 16 & 6.6 \\
\hline Total & 240 & 100 & & & & & \\
\hline \multicolumn{8}{|l|}{ Income( } \\
\hline $10,000-50,000$ & 84 & 35.0 & & 52 & 21.7 & 32 & 13.3 \\
\hline $51,000-100,000$ & 68 & 28.3 & & 39 & 16.3 & 29 & 12.0 \\
\hline $101,000-150,000$ & 53 & 22.1 & & 31 & 12.9 & 22 & 9.2 \\
\hline Above 150,000 & 35 & 14.6 & & 29 & 12.1 & 6 & 2.5 \\
\hline Total & 240 & 100 & & & & & \\
\hline
\end{tabular}

Source: Field Survey, 2015. 
Table 4. Distribution of respondents by Farm size, Occupation and Farming experience

\begin{tabular}{|c|c|c|c|c|c|c|c|}
\hline & & & & Male & & Female & \\
\hline Characteristics & Number & Percentage & Mean & No. & $\%$ & No. & $\%$ \\
\hline \multicolumn{8}{|l|}{ Farm size (acres) } \\
\hline Less than 2 & 35 & 14.6 & & 19 & 7.9 & 16 & 6.7 \\
\hline $2-4$ & 75 & 31.3 & & 47 & 19.6 & 28 & 11.7 \\
\hline $5-7$ & 63 & 26.3 & 2.6 & 54 & 22.5 & 9 & 3.8 \\
\hline $7-9$ & 41 & 17.0 & & 30 & 12.5 & 11 & 4.5 \\
\hline Above 10 & 26 & 10.8 & & 17 & 7.0 & 9 & 3.8 \\
\hline Total & 240 & 100 & & & & & \\
\hline \multicolumn{8}{|l|}{ Occupation } \\
\hline Farming & 98 & 40.8 & & 72 & 30 & 26 & 10.8 \\
\hline Trading & 48 & 20 & & 14 & 5.8 & 34 & 14.2 \\
\hline Fishing & 68 & 28.3 & & 50 & 20.8 & 18 & 7.5 \\
\hline Artisan & 10 & 4.2 & & 8 & 3.4 & 2 & 0.8 \\
\hline Civil servant & 16 & 6.7 & & 9 & 3.8 & 7 & 2.9 \\
\hline Total & 240 & 100 & & & & & \\
\hline \multicolumn{8}{|c|}{ Farming experience } \\
\hline $1-10$ & 23 & 9.6 & & 14 & 5.8 & 9 & 3.8 \\
\hline $11-20$ & 31 & 12.9 & & 25 & 10.4 & 6 & 2.5 \\
\hline 21-30 & 27 & 11.3 & & 17 & 7.1 & 10 & 4.2 \\
\hline $31-40$ & 38 & 15.8 & & 31 & 12.9 & 7 & 2.9 \\
\hline $41-50$ & 121 & 50.4 & & 96 & 40 & 25 & 10.4 \\
\hline Total & 240 & 100 & & & & & \\
\hline
\end{tabular}

Source: Field Survey, 2015.

Table 5. Farmers' Knowledge and Awareness of Climate Change

\begin{tabular}{|c|c|c|c|c|c|c|c|c|c|c|}
\hline Climate Change & \multicolumn{2}{|c|}{ Strongly Agreed } & \multicolumn{2}{|c|}{ Agree } & \multicolumn{2}{c|}{ Strongly Disagree } & \multicolumn{2}{c|}{ Disagree } & \multicolumn{2}{c|}{ Total } \\
\hline & No. & $\%$ & No. & $\%$ & No. & $\%$ & No. & $\%$ & No. & $\%$ \\
\hline Increasing flood & 126 & 52.5 & 60 & 25 & 40 & 16.7 & 14 & 5.8 & 240 & 100 \\
\hline $\begin{array}{c}\text { Increasing hot } \\
\text { temperature }\end{array}$ & 115 & 47.9 & 70 & 29.2 & 45 & 18.8 & 10 & 4.1 & 240 & 100 \\
\hline Unpredictable rain & 110 & 45.8 & 65 & 27.1 & 40 & 16.7 & 25 & 10.4 & 240 & 100 \\
\hline Shorter duration of rain & 97 & 40.4 & 100 & 41.7 & 35 & 14.6 & 8 & 3.3 & 240 & 100 \\
\hline $\begin{array}{c}\text { Late arrival of } \\
\text { rain }\end{array}$ & 112 & 46.7 & 78 & 32.5 & 31 & 12.9 & 19 & 7.9 & 240 & 100 \\
\hline $\begin{array}{c}\text { Increase in } \\
\text { drought incidence }\end{array}$ & 87 & 36.3 & 63 & 26.2 & 40 & 16.7 & 50 & 20.8 & 240 & 100 \\
\hline $\begin{array}{c}\text { Low rainfall } \\
\text { intensity }\end{array}$ & 106 & 44.2 & 91 & 37.9 & 23 & 9.6 & 20 & 8.3 & 240 & 100 \\
\hline $\begin{array}{c}\text { Drying up of } \\
\text { swamps }\end{array}$ & 124 & 51.7 & 99 & 41.3 & 10 & 4.1 & 7 & 2.9 & 240 & 100 \\
\hline $\begin{array}{c}\text { Variation in the rate of } \\
\text { weed growth }\end{array}$ & 100 & 41.7 & 85 & 35.4 & 38 & 15.8 & 17 & 7.1 & 240 & 100 \\
\hline
\end{tabular}

Source: Field Survey, 2015. 
Table 6. Perceived Climate Change Related Constraints

\begin{tabular}{|c|c|}
\hline Constraints & Mean \\
\hline Stunted growth & $3.2^{*}$ \\
\hline Wilting due to high temperature & $2.5^{*}$ \\
\hline High rate of weed growth & $2.8^{*}$ \\
\hline Incidence of Flooding & $2.6^{*}$ \\
\hline Occurrence of drought & 2.3 \\
\hline Prevalence of pests and diseases & 2.0 \\
\hline Low rainfall & $3.4^{*}$ \\
\hline Low rice yield & $2.7^{*}$ \\
\hline Increase in crop life cycle & 2.4 \\
\hline Premature rice ripening & $3.0^{*}$ \\
\hline
\end{tabular}

*Mean $\geq 2.5$, Source: Field Survey, 2015.

Table 7. Adaptation Practices of rice farmers

\begin{tabular}{|c|c|}
\hline Adaptation strategies & Mean \\
\hline Use of climate tolerant varieties & $3.3^{*}$ \\
\hline Early planting of rice & $2.5^{*}$ \\
\hline Diversification into non-farm activities & $3.5^{*}$ \\
\hline Mulching of paddy fields & $2.5^{*}$ \\
\hline Application of organic fertilizers & 2.2 \\
\hline Increased/reduced farm sizes cultivated & 2.3 \\
\hline Use of zero tillage & $2.9^{*}$ \\
\hline Use of early maturing rice variety & $3.7^{*}$ \\
\hline Transplanting of rice seed & 2.3 \\
\hline Access to rural services of credit and other necessary inputs. & 2.1 \\
\hline
\end{tabular}

*Mean $\geq 2.5$, Source: Field Survey, 2015.

Table 8. Barriers to Adaptation Practices of farmers

\begin{tabular}{|c|c|}
\hline Barriers & Mean \\
\hline Scarcity of improved varieties & $3.8^{*}$ \\
\hline Insufficient credit facilities & $2.7^{*}$ \\
\hline Poor Economic Status of Farmers & $2.5^{*}$ \\
\hline Low Subsidies on necessary inputs & 2.3 \\
\hline Inadequate Extension Services & $3.4^{*}$ \\
\hline Poor Information on Climate Change & $2.6^{*}$ \\
\hline Poor Knowledge of Mitigation and Adaptation & 2.2 \\
\hline Late Supply of Fertilizers and other Agro-Chemical & 2.4 \\
\hline
\end{tabular}

*Mean $\geq 2.5$ Source: Field Survey, 2015.

Table 9. Product Moment Correlation result showing correlation between farmers' perception of climate variability and impacts on rice yield.

\begin{tabular}{|c|c|c|c|}
\hline Variable pairs & r-value & p-value & Decision on significance \\
\hline Increasing flood and low rice yield. & 0.160 & 0.049 & Significant \\
\hline $\begin{array}{c}\text { Increasing hot } \\
\text { Temperature and wilting of rice }\end{array}$ & 0.158 & 0.043 & Significant \\
\hline Unpredictable rain and yield of rice & -0.173 & 0.034 & Significant \\
\hline $\begin{array}{c}\text { Shorter duration of rain and premature } \\
\text { rice ripening }\end{array}$ & 0.163 & 0.026 & Significant \\
\hline
\end{tabular}

*Correlation is significant at 0.05 


\subsection{Methods}

This study was conducted in ten communities of Agatu Local Government Area of Benue state, Nigeria. The communities were purposively chosen because of the prevalence of rice production and their high vulnerability to flooding. The communities include, Obagaji, Aila, Oweto, Utugolugwu, Obishu, Olegochepo, Inoli, Abugbe, Ocholonya and Ikpele. The second stage involved a simple random selection of 24 farmers from each of the ten communities. However, in the selection of farmers, the researcher took cognizance of gender sensitivity, hence a balance of males and females interviewee was observed (Table 1). The survey was conducted between July 2014 and July 2015. The period coincides with both early and late planting seasons.

Both primary and secondary data were used for this study. Primary data were collected through the use of a structured questionnaire administered to rice farmers in the study area, while secondary data came from National Bureau of Statistics (NBS), Benue Agricultural and Rural Development Authority (BENARDA), relevant texts, journals, proceedings and bulletin on both climate change and rice production. The secondary data elicited information on history of rice farming in developing countries, its economic importance and challenges facing its production. The secondary data were used to for literature review and to validate information gathered from primary data. The questionnaires were given to educated farmers to fill while uneducated ones were interviewed orally with the help of trained research assistants.

\subsection{Analytical Techniques}

Objective 1: Information elicited from respondents on socio-economic activities was analyzed using descriptive statistics such as frequency, counts and percentages. Objectives 2, 3 and 4: Respondents' responses to questions on Likert scale for agreement levels ( $1=$ strongly agree, $2=$ agree, $3=$ disagree, $4=$ strongly disagree) were analyzed using mean distribution. The values of the four responses were added to get 10 , which was divided further by 4 to get a mean of 2.5. Therefore, variables with mean of 2.5 and above were regarded as significant factors constraining rice production in the study area and vice versa. Data were presented using tables and charts.

\section{Results and Discussion}

\subsection{Socio Economic Characteristics of Respondents}

\section{Age, Sex and Marital Distribution}

Table 2 shows data on the distribution of respondents by age, sex and marital status. Table 2 reveals further that majority (38.3\%) of the respondents were between the ages of 36-45 years with a mean age of 42.8. This situation indicates that most rice farmers in Agatu LGA were within the active ages. This scenario also indicates that most youths are involved in rice farming in the study area, a situation which is favorable to the sustenance of rice production since youths have longer life span. The result is in consonance with the finding of (43) that about $84 \%$ of youths participated in land clearing, planting, fertilizer application, collection of fodder for livestock etc. in Imo state, Nigeria. Similarly, (44) confirmed that most youths in Ogba, Rivers State, Nigeria are much involved in rural development of which agriculture is a component.

Regarding gender, Table 2 illustrates that a larger proportion (68.8\%) of rice farmers were males. This implies that farming as an occupation is male dominated in the study area. In effect, (45) reported that 94\% of farmers in Ekit state were men and that most of the women are traders and food processors. However, (46) attributed low participation of women in yam production in Ekiti state to the drudgery and strenuous agronomic practices involved.

The marital status shows that there are 86 (35.8\%) who are married, 62 (25.8\%) are single, and 56 (23.3\%) are divorced, while widowed constitutes $36(15.1 \%)$ as revealed in Table 2. This means that married people were more involved in yam farming and may receive assistance from their spouses in carrying out some activities on the farm. This trend seems to agree with the findings of (47) in Gombe State, where they observed about $50 \%$ of their sampled farmers being married, while $13 \%$ and $17 \%$ were divorced and widowed, respectively

\section{Household size, Education and Income Status}

Table 3 expresses the distribution of respondents based on household size, education and income status. The household size indicates that majority (39.2\%) of the farmers had a household size of 6-10 members. This investigation reveals that there is adequate labour for rice production activities in the study area. (48) confirmed the aforementioned that household size as a proxy to labour availability reduces labour constraints.

On level of education attained, larger proportion (28.8\%) of the farmers had primary education. The foregoing indicates inadequate education among rice farmers in the study area, which can hamper comprehension of necessary rice production technologies and agricultural extension programmes on climate change. This claim is validated by (49) who submitted that education would likely make farmers more responsive to many agricultural extension programmes and policies. Accordingly, (50) identified formal education as a way to increase farmers' adaptive capacity to climate change. Therefore, the higher the educational qualification of the rice farmer, the more he/she is disposed to understand necessary information on climate change in rice production in the study area.

Regarding estimated annual income, majority (35\%) earned between 10,000-50,000 naira. This implies that rice 
farmers in Agatu LGA are of low income holdings, which could impact negatively on their aspiration to acquire improved varieties and other inputs required for adaptation to climate change. This is consistent with (51) who found a positive impact of farm income on the probability of adoption of climate change adaptation strategies in Nile basin of Ethiopia.

\section{Farm size, Occupation and Farm Experience}

Table 4 portrays information on farm size, occupation and farming experience in the area of study. Table 4 further indicates that greater proportion (30.8\%) of the rice farmers had farm sizes of 2-4 acres. This is an indication that these farmers are mainly small scale producers. This agrees with (52) that Nigerian farmers are small-scale farmers that cultivated small areas of land.

Table 4 indicates that a higher proportion $(40 \%)$ of respondents is into farming. Others are trading (20\%), fishing (28\%), Artisan (4.8\%) and civil servant (7.2\%).

On farming experience, table 4 indicates that nearly half (49.2\%) of the rice farmers in Agatu had rice farming experience of 41-50years. This implies that the farmers have sufficient knowledge of rice production and impacts of climate change on rice production in the study area. The result corroborates finding from (53) who reported that long farming experience is an advantage for increase in farm productivity since it encourages rapid adoption of farm innovation.

\subsection{Knowledge and Awareness of Climate Change}

Awareness is an indication of the consciousness and knowledge of climate change and its effects. It is a precondition for mitigation and adaptation to climate change. Table 5 expresses information on farmers' knowledge and awareness of climate change in Agatu LGA. Table 5 further indicates that more than half (126) of respondents strongly agreed that high incidence of flooding in the study area is an indication of climate change. Almost half (47.9\%) of the respondents cited increasing hot temperature, $45.8 \%$ affirmed unpredictable rain, $41.7 \%$ reported shorter duration of rain and $51.7 \%$ indicated drying up of swamps. The forgoing analysis of farmers' observation of climate variability is in harmony with the work of (54) in which 73\% of the respondents were of the opinion that temperature has been increasing over the past few decades. This is also in agreement with the study of (55) that the country has been experiencing temperature increase of about $0.2^{\circ} \mathrm{C}-0.3^{\circ} \mathrm{C}$ per decade in all its ecological zones.

\subsection{Climate Related Constraints to Rice Farming}

Table 6: displays information on farmers' perception of climate change related constraint to rice production in the area of study. Specific among the severe constraints (i.e. constraints with mean scores equal to or above 2.5 ) were
Low rainfall $(\bar{\chi}=3.4)$, stunted growth $(\bar{\chi}=3.2)$ premature rice ripening $(\bar{\chi}=3.0)$, high rate of weed growth $(\bar{\chi}=2.8)$, low rice yield $(\bar{\chi}=2.7)$ and incidence of flooding $(\bar{\chi}=2.6)$; whereas the less severe constraints (i.e. constraints with mean scores below 2.5) were increase in crop life cycle $(\bar{\chi}$ $=2.4)$, occurrence of drought $(\bar{\chi}=2.3)$ and prevalence of pests and diseases $(\bar{\chi}=2.0)$. This finding was reinforced by the work of (56) who confirmed that long-term climate variability influences sowing date, crop duration, crop yield and the management practices adopted in rice production.

\subsection{Adaptation Strategies to Climate change}

In an attempt to reduce the adverse impacts of climate change and variability, households in Agatu LGA employ several strategies to cope with climate change and variability. Adaptation, therefore, is the process by which stakeholders (including farmers) mitigate the adverse impacts of climate on their livelihoods and involves adjustments in lifestyle and economic structure in order to reduce the vulnerability of a system to climate change and vulnerability (57).Table 7 shows that at the micro-level, households in the case study villages employ several on-farm and off-adaptation strategies including, but not limited to, use of climate tolerant varieties $(\bar{\chi}=3.3)$, early planting of rice ( $\bar{\chi}=2.5)$, diversification into non-farm activities ( $\bar{\chi}=3.5)$, mulching of paddy fields $(\bar{\chi}=2.5)$, use of zero tillage $(\bar{\chi}=2.9)$ and use of early maturing rice variety $(\bar{\chi}=3.7)$. Table 7 further indicates that the afore mentioned strategies had mean scores greater than or equal 2.5, signifying that they were the key adaptation strategies evolved by farmers in the study area.

The results also suggest other adaptation strategies include, increased/reduced farm sizes cultivated $(\bar{\chi}=2.3)$, application of organic fertilizers $(\bar{\chi}=2.2)$, transplanting of rice seed $(\bar{\chi}$ $=2.3$ ), access to rural services of credit and other necessary inputs $(\bar{\chi}=2.1)$ in an attempt to reduce the negative impacts of climate variability on their livelihoods. The foregoing strategies had mean scores below 2.5, indicating that they were not very significant adaptation strategies employed by farmers in the study area. This investigation is in agreement with (58) who have shown that local farmers in SSA have rich and sophisticated agro-ecological knowledge useful for climate adaptation. These adaptations are adjudged to be effective as households have relied on them to cope with the adverse impacts of the climate on their livelihoods.

\subsection{Impediments to Adaptation Practices}

In an attempt to understand what restricts households from implementing adaptation strategies, households were asked to identify key barriers to climate adaptations. Barriers, therefore, are defined as factors, conditions or obstacles that reduce the effectiveness of adaptation strategies (59). The most commonly identified barriers which had mean scores greater than or equal to 2.5 were: scarcity of improved varieties $(\bar{\chi}=3.8)$, insufficient credit facilities ( $\bar{\chi}=2.7)$, poor economic status of farmers $(\bar{\chi}=2.5)$, inadequate extension services $(\bar{\chi}=3.4)$ and poor information on climate change $(\bar{\chi}$ 
$=2.6)$. These barriers constituted major hindrances to adaptation practices in the study area. Others cited low subsidies on necessary inputs $(\bar{\chi}=2.3)$, poor knowledge of mitigation and Adaptation $(\bar{\chi}=2.2)$ and late supply of fertilizers and other agro-chemical $(\bar{\chi}=2.4)$. Contrariwise, these identified barriers had mean scores lower than 2.5 indicating that they do not constitute major barriers to adaptation strategies in the area of study. The foregoing investigation is substantiated by (60) who reported that financial barriers due to lack of credit facilities are one of the most important obstacles hindering the implementation of appropriate climate adaptation strategies by farmers in Ethiopia. Furthermore, (61) suggest that inadequate information and awareness on climate change could potentially serve as barrier to successful implementation of adaptation practices.

\subsection{Correlation between Farmers' Perception of Climate Variability and Impact on Rice Yield}

The variable pairs indicated in Table 9 represent the significant correlation the hypothesized perception of climate change indicators has on the yield of rice in the study area.

Increasing flood was found to impact significantly on the yield of rice. The implication of this is that too much rainfall resulting in flooding destroys rice.

Increasing hot temperature was found to have significant correlation with wilting of rice. By inference, excessive heat has adverse effect on rice yield as it leads to wilting of crops.

Unpredicted rain also had significant impact on pests and diseases. This suggests that rainfall affects the availability of water for crop growth. Changes in rainfall patterns will likely affect the quantity and quality of water available for crop production. Consequently, unpredicted rainfall could lead to either drought or flooding, which has adversative effect on crop yield.

Shorter duration of rain and premature ripening were found to have significant relationship. This indicates that shorter duration of rainfall could result in low moisture for crop growth ensuing premature ripening and prevalence of pests and diseases.

In effect, the Product Moment Correlation Coefficient has affirmed that farmers' perception of climate variability is significantly correlated with its impacts on rice yield. Reports by similar studies support the preceding findings. For instance, (62) using the meteorological data from 1961 to 1998 for Navrongo, in Ghana reported a steady rise in temperature. The author submits that the steady monotonic increase in temperature levels could have serious adverse effects on agriculture in Ghana due to a sudden drop in crop yield when temperatures exceed the optimal for biological processes. Accordingly, (63) remarked that soil moisture for crops will also be affected by temperature increases, irrespective of any change in rainfall. In the same way, (64) observed that increases in evapotranspiration adversely affect crop production since grain crops (millet, sorghum, rice and maize) have shallow roots that obtain their moisture requirement from top soil.

Farmers' perceptions that temperature increased in the study area agrees with similar observations of farmers in other parts of Africa (65;66;67;68). On the other hand, (69) opined that the capacity of farmers to adapt to climate change can be significantly influenced by the level of awareness about climate change in their communities. Thus, (70) submitted that the first step towards adaptation is the perception of the problem.

\section{Conclusions}

This study identified the various climate adaptation strategies used by rice farmers in Agatu Local Government Area of Benue State, Nigeria. This is followed by the examination of the factors that impede the adoption of climate change adaptation strategies. The study also provided a description of the farmers' socioeconomic characteristics. The primary data used in this study were collected through structured questionnaires administered to 240 randomly selected rice farmers. The data was analyzed using both descriptive statistics and inferential statistics. The descriptive statistics includes frequencies, percentages and means while the inferential statistics used product Moment Correlation coefficient. Results illustrates that majority (38.3\%) of the respondents were between the ages of 36-45 years with a mean age of 42.8, larger proportion (68.8\%) of rice farmers were males and $86(35.8 \%)$ are married. In addition, majority (39.2\%) of the farmers had a household size of 6-10 members, larger proportion (28.8\%) of the farmers had primary education and majority (35\%) earned between 10,000-50,000 naira annually. More than half (126) of respondents had a fair knowledge of climate variability and its consequences. Results demonstrates that rice farmers adopted the following climate change adaptation strategies: use of climate tolerant varieties (3.3), early planting of rice (2.5), diversification into non-farm activities (3.5), mulching of paddy fields (2.5) , use of zero tillage (2.9) and use of early maturing rice variety (3.7) among others. Barriers to adaptation strategies identified include; scarcity of improved varieties (3.8), insufficient credit facilities (2.7), poor economic status of farmers (2.5), inadequate extension services (3.4) and poor information on climate change (2.6). The result of the Product Moment Correlation Coefficient showed that farmers' perception of climate change and variability are significantly related to the observed impact of climate variability in the study area.

\section{Recommendations}

This study has assessed the impact of climate variation on rice farming. In doing so, various standard quantitative and qualitative techniques were used and the results were 
reported accordingly. Based on those results, the following specific recommendations are made for maintaining or improving rice production in Agatu Local Government Area in the face of climate change.

I. Poor information on climate change is identified as a barrier to adaptation strategies. Hence, Government and other development actors should create useful meteorological centers in the rural areas to make accessible climate information to farmers via radio and television (interpretations in the language useful to farmers/rural communities). This will reinforce farmers' adaptability to climate change.

II. Inadequate extension services and poor knowledge of mitigation are noted as impediments to adaptation measures. Consequently, extension workers should be adequately trained in research centers and extension organizations on the complexities of climate change and their services should be made available to farmers.

III. Government should introduce improved rice variety that can adapt to varying environmental changes, with wide adaptability, able to adjust to drought and cope with flood as well as variations in temperatures in the study area.

IV. Government and NGOs should boost rice production in the study area by encouraging women participation through the provision of inputs at subsidized rates as incentives.

V. Government should enhance income holdings of farmers by encouraging irrigation as supplements to rain fed agriculture.

\section{REFERENCES}

[1] Changing Food Security: The Challenges of Climate Change in Ukpeko, Etsako East, Edo State Nigeria. Stephen, O. 2015, African Journal of Agriculture and Food Security, pp. 3(1):113-117.

[2] Gommes, R., El Hairech, T., Rosillon, D., Balaghi, R., and Kanamaru, H. Impacts of Climate Change on Agriculture in Morocco. FAO: World Bank, 2009.

[3] Jalloh, A., Nelson, G., Thomas, T., and Zougmoure, R.M. West African Agriculture and Climate Change. Washington DC: International Food Policy Research Institute. 2013.

[4] Climate Change: Mitigating Effects of Climate Change by Evolving Sustainable Agricultural Systems in Nigeria. Oyewole, C.I. 2015, Research Article, pp. 4(6), 106-115.

[5] Grain Physiochemical and Milling Qualities of Rice (Oryza sativa) cultivated in Southeast, Nigeria. Danbaba, N., Anounye, J., Gana, A., and Abo, M. 2013, Journal of Applied Agricultural Resources, pp. 5:61-71.

[6] Climate change adaptation through rice production in regions with high poverty levels. Wassmann, R. and Dobermann, A. 2007, Journal of ICRISAT Agricultural Research, pp. 4 (1), $1-24$.
[7] Agarwal, A. Forecasting rice yield under climate change scenarios for Northeast Thailand. Thailand: MS Thesis. Department of water engineering and management, Asian Institute of Technology, 2008.

[8] "Analysis of socio economic factors influencing the adoption of rice technologies by farmers in Borno State, Nigeria. Abu, I.A., Pur, J.T. and Ogunbameru, B.O. 2011, Adamawa State University Journal of Agricultural Sciences, pp. 1(1),40-45.

[9] Adoption of Improved Rice Varieties among Small-Scale Farmers in Katcha Local Government Area of Niger State, Nigeria. Jirgi, A, J., Abdulrahman, M. and Ibrahim, F.D. 2009, Journal of Agricultural Extension, pp. 13(1), 95-101.

[10] Pattern and Trend of Rice Production in the Federal Capital Territory, Abuja, Nigeria. Hassan, S.M. 2014, Confluence Journal of environmental Studies, pp. 9:1-7.

[11] Akinyosoye, V.O. Tropical Agriculture. Ibadan : Macmillan Publishers Limited, 1991.

[12] Rice growing environments and biophysical constraints in different agroecological zones of Nigeria. Singh, B., Fagade, S., Ukwungwu, M., Williarn, C., Jagtap, S., Oladimeji, O., . . . Okhidievbie, 1: 35-44., s.l. : Met. J., 1997, Vol. 2 .

[13] Demand Analysis for Rice in Nigeria. Erhabor, P.O.I. and Ojogho, O. 2 :66-74, s.l. : Journal of food Technology, 2011, Vol. 9.

[14] Climate variability, vulnerability and effectiveness of farm-level adaptation options: the challenges and implications for food security in South-western Cameroon. Molua, E.L. s.l. : Environment and Development Economics, 2002, Vols. 7: 529-545.

[15] IPCC. Climate Change 2007: impacts, adaptation and vulnerability: contribution of Working Group II to the fourth assessment report of the Intergovernmental Panel on Climate Change. Cambridge, UK. : Cambridge University Press, 2007.

[16] Vulnerability and adaptation to climate risks in Ontario agriculture. Reid, S., Smit, B., Caldwell, W., \& Belliveau, S. 4: 609-637, s.l.: Mitigation and Adaptation Strategies for Global Change, 2007, Vol. 12.

[17] The Effect of Irrigation Technology on Groundwater Use. Lisa, Pfeiffer and Cynthia Lin, C.Y. 3:1-6, s.l. : Agricultural and Applied Economics Association, 2010 , Vol. 25.

[18] A theoretical analysis of economic incentive policies encouraging agricultural water conservation. Huffaker, R. and Whittlesey, N. 1:37-55, s.l.: Water Resources Development, 2003, Vol. 19.

[19] Herbivory in global climate change research: direct effects of rising temperature on insect herbivores. Bale, J.S. and Masters, G.J. 1: 1-16, s.l. : Global Change Biology , 2002, Vol. 8.

[20] Plant growth and competition at elevated CO2 on winners, losers and functional groups. Poorter, H. and Navas, M.L. s.l. : New Phytologist, 2003, Vols. 157: 175-198.

[21] IPCC. Climate Change 2007: Impacts, Adaptation and Vulnerability . In M. Parry, O. Canziani, J. Palutikof, P. van der linden, \& C. Hanson. Contribution of Working GroupII to the Fourth Assessment Report of the IPCC. Cambridge : Cambridge University Press, 2007.

[22] Variability in climatology and agricultural production in China 
in Association with the East Asia summer monsoon and El Nino south oscillation. Tao, F., Okozawa, M., Zhang, Z., Hayashi, Y., Grassl, H., \& Fu, C s.l. : Climate Research, 2004, Vols. 28: 23-30.

[23] Prakash, K. K. The Impact of Climate Change on Rice Production in Nepal. Kathmandu, Nepal : SANDEE, Working Paper No. 85-14, 2014.

[24] Climate Change and Rice Yields in Diverse Agro-Environments of India. II Effects of Uncertainties in Scenarios and Crop Models on Impact Assessment. Aggarwal, P.K. and Mall, R.K. s.l. : Climate Change, 2002, Vols, 52:331-333.

[25] Indigenous people's perception on climate change and adaptation strategies in Jama'a Local Government Area of Kaduna State, Nigeria. Ishaya, S. and Abaje, I.B. 2008, Journal of Geography and Regional Planning, pp. 1(8), 138-143.

[26] A General Adaptation Strategy for Climate Change Impacts on Paddy Cultivation: Special Reference to the Japanese Context. Watanabe, T. and Takashil, K. s.l. : Paddy Water Environment, 2009, Vols. 7: 313-320.

[27] Strengthening Solidarity among the Asian Monsoon Countries for establishing Sustainable Water Policy for Agriculture. T., Hideaki. s.l. : Paddy Water Environment, 2008, Vols. 7:341-347.

[28] Climate Change: Mitigating Effects of Climate Change by Evolving Sustainable Agricultural Systems in Nigeria. Oyewole, C.I. 6:106-115, s.l. : Research Article , 2015, Research Article, Vol. 4, pp. 4(6),106-115.

[29] Grain Physiochemical and Milling Qualities of Rice (Oryza sativa) cultivated in Southeast,Nigeria. Danbaba, N., Anounye, J., Gana, A., \& Abo, M s.l. : Journal of Applied Agricultural Resources, 2013, Journal of Applied Agricultural Resources, Vols. 5:61-71., pp. 5:61-71.

[30] The Effects of Land Tenure Practice on Agricultural Output in Agatu Local Government Area of Benue State,Nigeria. Idoma, K. and Ismail, M. 5:212-219, s.l. : Journal of Development and Agricultural Economics, 2014, Journal of Development and Agricultural Economics, Vol. 6, pp. 6(5),212-219.

[31] Analysis of Awareness and Adaptation to Climate Change among Farmers in the Sahel Savanna Agro-ecological zone of Borno State, Nigeria. Idrisal, Y.L. 2012, British Journal of Environmental and Climate Change, pp. 216-226.

[32] Determinants of youths' participation in Rural Agriculture in Imo state, Nigeria. Nnadi, F.N. and Akwiwu, C.D. 2008, Journal of Applied Sciences, pp. 8:328-333.

[33] Analysis of Climate Change and Rural Farmers’ Perception in North Central Nigeria. Falaki, A. A., Akangbe, J. A. and Ayinde, O. E. 2013, Journal of Human Ecology, pp. 43(2): 133-140.

[34] Technical Inefficiency and Competitiveness in Production: The Case of Rice Farmers in Niger State,Nigeria. Rahji, M.A. and Omotesho, O.A. 1: 61-79, s.l. : Agrosearch, 2006, Vol. 8.

[35] Economic Viability of Processing and Marketing of Rice in Uzouwani Local Government Area of Enugu State, Nigeria. Emeka, N. and Ugwu, J.N. 17, s.l. : Developing Country
Studies, 2015, Vol. 5. ISSN 2224-607X (Paper) ISSN 2225-0565 (Online).

[36] Osagie, C. 2015 rice importation ban: Disregard US report, FG urged. [Online] May 17, 2014. [Cited: December 1, 2016.] http://www.thisdaylive.com/articles/2015-rice-importation-ba n-disregard-us-report-fgurged/.

[37] The Impact of Rice Production, Consumption and Importation in Nigeria: The Political Economy Perspectives. Terwase, I.T. and Madu, A.Y. 4, s.l. : International Journal of Sustainable Development and World Policy, 2014, Vol. 3.

[38] Imolehin, E.D. and Wada, A.C. Meeting the Rice Production and Consumption Demands of Nigeria with Important Technologies. s.l. : FAO: Agriculture and Consumer Protection Unit, 2000.

[39] Anonymous. Research Highlights. In Nigeria Agricultural Research Project (NARP). s.l. : World Bank Assisted 1997 Annual Report, p. 3., 1997.

[40] Are there social limits to adaptation to climate change? Adger, W., Dessai, S., Goulden, M., Hulme, M., Lorenzoni, I., Naess, L., . . . Wreford, A. 2009, Climatic Change, pp. 93(3), 335-354.

[41] Gbue, S. My achievement in 242 days in the office (Agatu Local Government). Oshogbo: Phabimson, 1999.

[42] Adaji, S. Rice Production in Agatu Local Government Area of Benue State. Makurdi: Unpublished B.sc Project. Benue State University. 2000.b

[43] Youth Involvement in Rural Development Activities in Ogba district of Rivers state, Nigeria. Obuh, J. 2005, Journal of Agriculture and social Resources, pp. 5:48-53.

[44] Integrating Smallholder Food Crop Farmers into the National Policy for commercialization and Large Scale Agriculture in Nigeria: A case study of Ekiti state. Oluwasola, O. 2012, International Journal of Agriculture and Forestry, pp. 2(5), 247-256.

[45] Farmers adaptation Strategies to the Effects of Climate Variation on Yam Production: A Case Study in Ekiti State, Nigeria. Oluwasusi, J.O. and Tijani, S.A. 2013, Agro search, pp. 13(2), 20-31.

[46] Role of Women in Agricultural Development and their Constraints: A case Study of Biri Local Government Area of Gombe State, Nigeria. Fabiyi, E., Danladi, B., Akande, K. and Mahmood, Y. 2007, Pakistan Journal of Nutrition, pp. 6(6), 676-680.

[47] Adaptation to Climate Change by Farmers in Mkurdi, Nigeria. Blessing, E. and Goodness, C. A. 2015, Journal of Agriculture and Ecology Research International, pp. 2(1): 46-57.

[48] Olayide, S.O. Nigerian Small Farmers: Problems and Prospects in Integrated Rural Development. CARD. pp. 72-75.: CARD., 1992.

[49] Adoption of improved cassava production technologies by small scale farmers in Bendel State. Obinne, C.P.O. 1991, Journal of Agricultural Science and Technology, pp. 1(1), 12-15.

[50] Indigenous people's perception on climate change and adaptation strategies in Jama'a Local Government Area of Kaduna State, Nigeria. Ishaya, S. and Abaje, I.B. 2008, 
Journal of Geography and Regional Planning, pp. 1(8), 138-143.

[51] Climate Change and Rice Yields in Diverse Agro-Environments of India. II Effects of Uncertainties in Scenarios and Crop Models on Impact Assessment. Aggarwal, P.K. and Mall, R.K. s.l. : Climate Change, 2002, Vols. 52:331-333.

[52] Oladikpo, E. The Challenge of Climate for Nigeria: An Overview. In E. Iguisi, Ati, O.F., R. Yusuf, and A. Ubugu.Climate Change Impacts: Risks and Opportunities. Zaria: Proceedings of the International Conference of the Nigerian Meteorological Society held at Ahmadu Bello University, Zaria 13-17 November, 2011, 2011, pp. 22-44.

[53] Agronomic Impacts of Climatic Variability on Rice Production in the Philippines. Lansigan, F.P., de los Santos, W.L. and Coladilla, J.O. 2000, Agriculture, Ecosystems and environment, pp. 82(1-3), 129-137.

[54] An anatomy of adaptation to climate change and variability. Smith, B., Burton, I., Klein, R., and Wandel, J. 2000, Climatic Change, pp. 45(1), 223-251.

[55] Indigenous knowledge related to climate variability and change: insights from droughts in semi-arid areas of former Makueni district, Kenya. Speranza, C., Kiteme, B., Ambenje, P., Wiesmann, U. and Makali, S. 2010, Climatic Change, pp. 100(2), 295-315.

[56] A framework to diagnose barriers to climate change adaptation. Moses, S.C. and Ekstrom, J.A. 2010, Proceedings of the National Academy of Sciences, pp. 107(51), 22026-22031.

[57] Adaptation to climate change in Ethiopia and South Africa: options and constraints. Bryan, E., Deressa, T.T., Gbetibouo, G.A. and Ringler, C. 2009, Environmental Science and Policy, pp. 12(4), 413-426.

[58] Climate change adaptation through rice production in regions with high poverty levels. Wassmann, R. and Dobermann, A. 1:1-24, s.l. : Journal of ICRISAT Agricultural Research, 2007, Journal of ICRISAT Agricultural Research, Vol. 4, pp. 4 (1), $1-24$.

[59] "Analysis of socio economic factors influencing the adoption of rice technologies by farmers in Borno State, Nigeria. Abu, I.A., Pur, J.T. and Ogunbameru, B.O. 1:40-45, s.l. : Adamawa State University Journal of Agricultural Sciences, 2011,
Adamawa State University Journal of Agricultural Sciences, Vol. 1, pp. 1(1),40-45.

[60] Adoption of Improved Rice Varieties among Small-Scale Farmers in Katcha Local Government Area of Niger State, Nigeria. Jirgi, A,J., Abdulrahman, M. and Ibrahim, F.D. 1:95-101, s.l. : Journal of Agricultural Extension, 2009, Journal of Agricultural Extension, Vol. 13, pp. 13(1), 95-101.

[61] Pattern and Trend of Rice Production in the Federal Capital territory,Abuja, Nigeria. Hassan, S.M. s.l. : Confluence Journal of environmental Studies, 2014, Confluence Journal of environmental Studies, Vols. 9:1-7, pp. 9:1-7

[62] Impact of climate change on agriculture and farmers coping strategies in the upper east region of Ghana. Ofori-Sarpong, E. s.l. : West African Journal Applied Ecology, 2001, Vols. 2:2135.67 .

[63] Review: soil management in mitigating the adverse effects of climate change. Bhatti, A.U. and Khan, M.M. s.l. : Soil Environment, 2012, Vols. 31:1-10.

[64] Impact of climate variability on soil moisture availability in North Eastern Ghana: implications for agricultural extension and rural development. Obeng, F.K. s.l. : International Journal of Agricultural Science, 2014, Vols. 4:109-118. 2228-6322.

[65] Climate change and variability: perception and adaptation strategies of pastoralists and agro-pastoralists across different zones of Burkina Faso. Zampaligré, N., Dossa, L.H. and Schlecht, E. s.l. : Region Environmental Change., 2014, Vols. 14:769-783.

[66] Farmers' perceptions and adaptations to climate change in sub-Sahara Africa: a synthesis of empirical studies and implications for public policy in African agriculture. . Juana, J.S., Kahaka, Z. and Okurut, F.N. 4:122-135, s.l. : Journal of Agricultural Science, 2013, Vol. 5. 1916-9752, E-IS.

[67] Smallholder farmers' perception of the impacts of climate change and variability on rain-fed agricultural practices in semi-arid and sub-humid regions of Kenya. Kalungu, J.W., Filho, W.L. and Harris, D. 7:129-140., s.l. : Journal Environmental Earth Science, 2013, Vol. 3. 2225-0948.

[68] Farmers' perception of climate change in the Ejura-Sekyedumase District of Ghana. Kemausuor, F., Dwamena, E. and Bart-plange, A. s.l. : ARPN Journal of Agricultural and Biological Sciences, 2011, Vols. 6:26-37. 